\title{
PENGGUNAAN STRUKTUR FRASE EKSOSENTRIS DIREKTIF DAN FUNGSINYA DALAM NOVEL NEGERI 5 MENARA (A. FUADI) DAN IMPLIKASINYA DALAM PEMBELAJARAN BAHASA INDONESIA DI SMA
}

\author{
Bayu Ardianto \\ LPMP Sulawesi Barat \\ E-mail: bayu.ardiyanto@kemdikbud.go.id
}

\begin{abstract}
ABSTRAK
Penelitian ini difokuskan penggunaan struktur frase eksosentris direktif dan fungsinya dalam wacana novel Negeri 5 Menara. Instrumen penelitian ini yaitu peneliti sendiri dibantu dengan tabel analisis. Hasil penelitian ini menunjukkan terdapat 1280 frase eksosentris direktif yang dikaji berdasarkan pola struktur dan maknanya dalam novel Negeri 5 Menara. Makna tempat yang paling sering muncul adalah makna tempat posisional dalam pola yang paling sering muncul yaitu Prep. Dasar (di) + N. Hal ini disebabkan makna frase eksosentris direktif ditentukan dari preposisi yang digunakannya. Hasil penelitian ini dapat diimplikasikan dalam pembelajaran kompetensi dasar yang mengarahkan siswa SMA untuk memiliki kompetensi menganalisis frase novel dalam Kurikulum 2013.
\end{abstract}

Kata kunci: frase eksosentris direktif, Negeri 5 Menara, pembelajaran bahasa

\section{THE USE OF DIRECTIVE EXOCENTRIC PHRASE STRUCTURE AND ITS FUNCTION IN NEGERI 5 MENARA NOVEL (BY A. FUADI) AND IMPLICATIONS IN INDONESIAN LANGUAGE LEARNING IN SENIOR HIGH SCHOOL}

\begin{abstract}
This study focused on the use of exocentric directive phrase structure and its function in the discourse of Negeri 5 Menara novel. The instrument of this research is the researcher himself assisted with the analysis table. The results of this study indicate there are 1280 directive exocentric phrases studied based on the structure pattern and its meaning in Negeri 5 Menara novel. The most common place meaning is the positional place in the most common pattern of Prep. Basic (di) $+\mathrm{N}$. This is due to the meaning of the exocentric directive phrase determined from the preposition it uses. The results of this study can be implied in basic competence learning that directs senior high school students to have the competence of analyzing phrase in Curriculum 2013.
\end{abstract}

Keywords: exocentric directive phrase, Negeri 5 Menara, language learning 


\section{PENDAHULUAN}

Peranan bahasa penting bagi kehidupan manusia menyebabkan pembelajaran bahasa menjadi aspek penting yang harus diajarkan di sekolah sejak dini. Pembelajaran bahasa dimaksudkan agar pemakainya dapat menggunakan bahasa yang efektif dan efisien dalam berkomunikasi baik secara lisan maupun secara tertulis. Saat ini, dalam penerapan Kurikulum 2013, memberikan kesempatan untuk menganalisis novel lebih utuh termasuk melihat bagian atau sisi kebahasaannya.

Pembelajaran bahasa untuk mengarahkan siwa menguasai empat keterampilan berbahasa sesungguhnya berkaitan antara satu dengan yang lainnya. Jadi guru dapat memanfaatkan satu bahan ajar untuk mengajarkan beberapa keterampilan berbahasa sekaligus. Sesuai dengan hal tersebut, guru dapat menggunakan karya sastra seperti novel sebagai bahan ajar untuk mengajarkan aspek kebahasaan di samping juga mengajarkan aspek kesastraan sebab pada dasarnya kebahasaan dan kesastraan adalah dua aspek yang tidak dapat dipisahkan satu sama lain.

Dengan adanya pemanfaatan bahan ajar untuk memberikan pemahaman mengenai aspek kebahasaan dan aspek kesastraan sekaligus, diharapkan siswa dapat mencapai tujuan pembelajaran dengan baik. Pemberian pembelajaran yang lebih mendalam mengenai bahasa sangat diperlukan sehingga siswa tidak hanya mampu menangkap bahasa dengan baik tetapi juga mampu memproduksi bahasa secara runtut, logis, dan mudah dipahami.

Novel merupakan salah satu karya sastra yang banyak digemari siswa. Novel merupakan ragam wacana tulis memiliki panjang tidak kurang dari 50.000 kata. Jumlah kata dalam novel sifatnya adalah relatif. Dalam proses penulisannya, pengarang menyusun kata demi kata dengan sedemikian rupa hingga kemudian terciptalah 
serangkaian wacana yang utuh dalam bentuk cerita yang muncul sebagai suatu penggambaran tentang kehidupan sehari-hari yang terjadi di masyarakat meskipun kejadian yang digambarkan dalam novel tersebut hanya bersifat rekaan.

Pengkajian novel melalui segi kebahasaan dapat dilakukan dengan cara melepaskan bagian-bagian kebahasaan di dalam novel menjadi bagian yang lebih kecil, seperti kalimat, klausa, frasa, kata, atau bahkan morfem. Pada pengkajian yang semacam ini hanya akan dilihat kalimat-kalimat penyusun wacana yang terdapat dalam novel tersebut. Pengkajian bahasa di dalam sebuah novel itu sangat diperlukan untuk membantu pembaca memahami sebuah novel secara menyeluruh.

Pengkajian bahasa yang membicarakan tentang hubungan kata-kata dalam sebuah kalimat termasuk ke dalam bidang kajian sintaksis. Pembahasan dalam sintaksis difokuskan mengenai struktur sintaksis atau satuan-satuan sintaksis yang terkandung di dalam novel. Satuan-satuan sintaksis tersebut berupa kata, frase, klausa, kalimat, dan wacana. Keempat satuan sintaksis (frase, klausa, kalimat, dan wacana) dibentuk oleh kata. Kata sebagai sebuah elemen dasar dapat berdiri sendiri atau bergabung dengan kata-kata lainnya. Kata yang bergabung dengan kata lainnya yang tidak memiliki unsur predikatif dan masih menempati satu fungsi sintaksis yang sama di dalam sebuah kalimat disebut dengan frase. Istilah frase digunakan sebagai satuan sintaksis yang satu tingkat berada di bawah klausa, atau satu tingkat berada di atas satuan kata. Karena frase itu mengisi salah satu fungsi sintaksis, maka salah satu unsur frase itu tidak dapat dipindahkan secara keseluruhan sebagai satu kesatuan. Frase yaitu suatu satuan gramatik yang terdiri dari dua kata atau lebih yang tidak melampaui batas fungsi unsur klausa (Ramlan, 2001). 
Frase berperan penting untuk memperkaya kosakata sebuah kalimat. Pemilihan frase dalam sebuah kalimat dapat memperjelas kata secara spesifik dan memperkecil ruang lingkup makna yang muncul. Frase yang memiliki sifat nonpredikatif dapat membantu memperjelas maksud penyampaian cerita. Dalam pembelajaran bahasa di SMA, frase menjadi bagian penting dalam peningkatan kemampuan berbahasa. Hanya saja, menurut pengamatan penulis, pembelajaran frase di sekolah belum mendapatkan porsi yang cukup. Buku teks pegangan siswa memuat materi frase yang sangat terbatas dan bersifat umum.

Pengenalan jenis frase yang disajikan buku teks baru berkisar pada frase endosentris dan frase eksosentris secara global. Di sekolah, frase endosentris lebih banyak dipelajari. Hal ini disebabkan oleh minimnya jumlah frase eksosentris dibandingkan dengan frase endosentris. Frase endosentris dibentuk dari kata penuh (fullword) yang merupakan kelas terbuka sehingga mempunyai kemungkinan untuk mengalami proses morfologis, sedangkan frase eksosentris dirangkai oleh kata tugas (functionword) yang merupakan kelas tertutup sehingga tidak mengalami proses morfologis.

Preposisi merupakan kata tugas (functionword). Preposisi yang menjadi perangkai dalam frase eksosentris menyebabkan munculnya frase preposisional atau frase eksosentris direktif. Frase ini memiliki dua komponen yaitu perangkai dan sumbu. Frase eksosentris direktif ini memiliki struktur, makna, dan fungsi yang beragam dalam sebuah kalimat. Contohnya, dalam sebuah kalimat terdapat frase dengan ujung telunjuk kananku dan frase mengingat akan. Kedua frase tersebut tentunya memiliki struktur dan makna yang berbeda. Frase dengan ujung telunjuk kananku memiliki perangkai dengan dan memiliki sumbu atau poros ujung telunjuk kananku dan memiliki makna alat. Jika 
frase dengan ujung telunjuk kananku memiliki perangkai di depan dan poros atau sumbunya terletak di belakang, frase mengingat akan justru memiliki poros atau sumbu yang terletak di depan yaitu mengingat dan diikuti oleh perangkai akan. Frase mengingat akan memiliki makna yang berbeda dengan frase dengan ujung telunjuk kananku, frase mengingat akan menunjukkan makna perihal.

Kridalaksana (1985) menggolongkan makna frase eksosentris direktif meliputi

1) tempat: $d i$, pada;

2) arah atau peralihan: ke, dari, kepada, terhadap;

3) perihal: tentang, akan;

4) tujuan: untuk, buat;

5) sebab: karena, lantaran;

6) asal: dari; dan

7) penjadian: oleh.

Chaer (2009) frase eksosentris direktif adalah frase yang berperangkai preposisi, sedangkan frase eksosentris nondirektif adalah frase yang berperangkai lainnya. Penggunaan frase eksosentris direktif dalam novel berkaitan dengan masalah penjelasan latar baik berupa latar tempat, waktu, maupun suasana yang terdapat dalam sebuah novel. Frase eksosentris direktif di dalam sebuah kalimat biasanya menempati fungsi keterangan. Oleh karena itu, frase eksosentris direktif dapat memberikan penjelasan atau informasi berupa keterangan mengenai hal yang tokoh perbuat. Berbagai bentuk struktur dan makna frase eksosentris direktif akan banyak ditemukan dalam sebuah novel karena kalimat novel merupakan susunan informasi yang menceritakan suatu masalah dari berbagai sudut pandang, baik dari sudut pandang tokoh utama yang 
diceritakan, atau dari sudut pandang pengarang yang menceritakan atau juga dari sudut pandang benda tokoh lain di dalam novel tersebut.

Selain bergamnya struktur dan makna frase eksosentris direktif dalam novel juga disebabkan oleh kekompleksan masalah dan alur cerita yang termuat di dalamnya. Pemahaman tentang frase eksosentris direktif sangat penting dalam rangka memahami informasi tambahan yang terkandung dalam sebuah kalimat. Hal ini disebabkan karena bagaimana pun kalimat digunakan untuk menyampaikan informasi baik secara lisan maupun secara tertulis, sehingga kejelasan fungsi keterangan yang biasanya ditempati oleh frase eksosentris direktif mempengaruhi kejelasan informasi yang dikandung oleh kalimat dalam satuan bahasa yang lebih besar yaitu wacana novel.

Salah satu novel yang di dalamnya banyak terdapat penggunaan frase eksosentris direktif dengan pola struktur dan makna yang beragam adalah novel karangan A. Fuadi (2009) yang berjudul Negeri 5 Menara. Novel ini merupakan novel pertama dari trilogi Negeri 5 Menara. Di dalam novelnya ini, A. Fuadi menggunakan bahasa yang lugas dan mudah dipahami, tanpa banyak menggunakan kata-kata kiasan. A. Fuadi kebanyakan menggunakan struktur kalimat yang lengkap, yang terdiri dari subjek $(\mathrm{S})$, predikat $(\mathrm{P})$, objek $(\mathrm{O})$, dan keterangan $(\mathrm{K})$, sehingga frase eksosentris yang biasanya menempati fungsi keterangan dalam sebuah kalimat akan banyak ditemukan dalam novel ini.

Novel ini berisi kisah inspiratif tentang kehidupan seorang anak pondok. Negeri 5 Menara ini juga sangat sarat akan nilai-nilai kehidupan. Banyak hal yang menarik dari novel ini, tidak hanya ceritanya yang inspiratif, tetapi juga gaya bercerita A. Fuadi yang khas, yang menyelipkan candaan-candaan khas pondok di dalamnya. Penggunaan gaya bahasa dalam kedua novel ini sangat hidup, sehingga dapat membuat pembaca merasa 
ikut masuk ke dalam cerita tersebut. Berdasarkan uraian di atas, frase eksosentris direktif merupakan frase eksosentris yang berperangkai preposisi yang biasanya menempati fungsi keterangan di dalam kalimat. Frase eksosentris direktif mempunyai peran dalam memperjelas informasi yang terdapat dalam kalimat sehingga informasi yang terdapat dalam sebuah wacana dapat terungkap dengan baik, dalam hal ini adalah wacana novel.

\section{METODE}

Metode penelitian ini menggunakan yaitu deskriptif kualitatif dengan teknik analisis isi. Penerapan metode ini dinilai sesuai dengan permasalahan, karena menggambarkan keadaan sesungguhnya yakni teknik analisis bahasa secara struktural untuk menemukan satuan-satuan bahasa secara bertahap membentuk pola struktur, makna, dan fungsi frase eksosentris direktif dalam novel Negeri 5 Menara karangan A. Fuadi. Penulis berusaha menemukan frase eksosentris direktif pada novel Negeri 5 Menara karangan A. Fuadi. Setelah data terkumpul, penulis berusaha mendeskripsikan frase eksosentris direktif tersebut dengan menganalisis pola struktur, makna, dan fungsi frase eksosentris direktif.

\section{HASIL DAN PEMBAHASAN}

Berdasarkan hasil analisis, melalui Tabel 1dapat dilihat bahwa dari 1280 frase eksosentris direktif, terdapat 712 frase eksosentris direktif atau sekitar 55,63\% yang berpola Prep. Dasar + (N/A/Num), terdapat 75 frase eksosentris direktif atau sekitar 5,86\% yang berpola Prep. Dasar + Prep.Denominal, didapatkan pula 177 frase eksosentris direktif atau sekitar 13,83\% yang berpola Prep. Dasar + Nomina Lokasi + 
N. Tempat. Selain itu, terdapat 2 frase eksosentris direktif atau sekitar $0,16 \%$ yang berpola Prep.Deverbal + Prep. Dasar, terdapat 189 frase eksosentris direktif atau sekitar 14,77\% yang berpola Prep.Denominal + (V/N/A/Pr), terdapat 81 frase eksosentris direktif atau sekitar 6,34\% yang berpola Prep.Deverbal $+(\mathrm{V}, \mathrm{Pr}, \mathrm{Aj})$, terdapat 6 frase eksosentris direktif atau sekitar $0,47 \%$ yang berpola Prep. Dekonjungsional+ (N/V) dan terdapat 38 frase eksosentris direktif atau sekitar 2,97\% yang berpola Prep. Deadverbial+ (N/V).

Tabel 1. Rekapitulasi Data Struktur Frase Eksosentris Direktif dalam Novel Negeri 5 Menara karangan A. Fuadi

\begin{tabular}{|c|c|c|c|c|c|c|c|c|c|c|c|}
\hline & \multicolumn{10}{|c|}{ Struktur Frase Eksosentris Direktif } & \\
\hline & 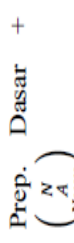 & 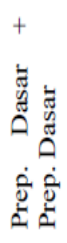 & 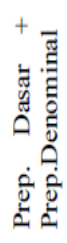 & 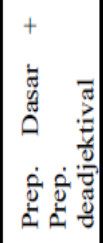 & 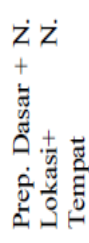 & 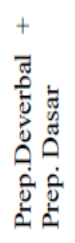 & مُ & 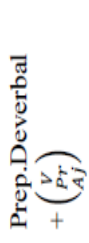 & 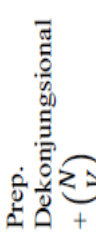 & 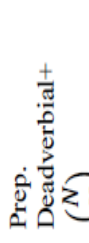 & Total \\
\hline Jumlah & 712 & 0 & 75 & 0 & 177 & 2 & 189 & 81 & 6 & 38 & 1280 \\
\hline$\%$ & 55,63 & 0 & 5,86 & 0 & 13,83 & 0,16 & 14,77 & 6,34 & 0,47 & 2,97 & 100 \\
\hline
\end{tabular}

Dalam penelitian ini terdapat dua pola frase eksosentris direktif yang tidak ditemukan yaitu Prep. Dasar + Prep. Dasar dan Prep. Dasar + Prep. Deadjektival. Namun, dalam penelitian ini juga ditemukan struktur frase yang tidak termasuk ke dalam penggolongan struktur frase menurut Kridalaksana, yaitu Prep. Dekonjungsional+, dan Prep. Deadverbial + . Kemunculan struktur baru ini menyebabkan munculnya makna baru yaitu makna perbuatan bersamaan yang dihasilkan oleh preposisi deadverbial sambil. Hal ini mungkin terjadi karena bahasa yang digunakan dalam novel adalah bahasa yang digunakan dalam percakapan seharihari.

Berdasarkan data yang dideskripsikan di atas, dapat diinterpretasikan bahwa dari 1280 frase eksosentris direktif dalam novel Negeri 5 Menara karangan A. Fuadi 
ditemukan kecenderungan frase eksosentris direktif yang berpola Prep.Dasar + (N/A/Num) sebanyak 712 frase atau sekitar 55,63\%. Frase eksosentris direktif yang berpola Prep. Dasar + (N/A/Num), terdapat 75 frase atau sekitar 5,86\% yang berpola Prep. Dasar + Prep.Denominal, didapatkan pula 177 frase atau sekitar 13,83\% yang berpola Prep. Dasar + Nomina Lokasi + N. Tempat. Selain itu, terdapat 2 frase eksosentris direktif atau sekitar 0,16\% yang berpola Prep.Deverbal + Prep. Dasar, terdapat 189 frase atau sekitar 14,77\% yang berpola Prep.Denominal $+(\mathrm{V}, \mathrm{N}, \mathrm{A}, \mathrm{Pr})$, terdapat 81 frase atau sekitar 6,34\% yang berpola Prep.Deverbal $+(\mathrm{V}, \mathrm{Pr}, \mathrm{Aj})$, terdapat 6 frase atau sekitar $0,47 \%$ yang berpolaPrep. Dekonjungsional+ (N, V). Frase eksosentris direktif dengan struktur Prep.Deadverbial+ (N/V) ditemukan paling sedikit yaitu sebanyak 38 frase atau sekitar 2,97\%.

Kecenderungan lebih banyaknya frase eksosentris direktif yang berpola Prep. Dasar + (N/A/Num) di dalam novel ini karena Prep. Dasar memiliki jenis dan makna yang beragam dibandingkan dengan ketujuh pola lainnya sehinggapengarang memiliki kecenderungan untuk memilih pola ini untuk melengkapi ceritanya.

Adapun contoh analisis frase eksosentris direktif yang berpola Prep. Dasar + (N/A/Num) yang ditemukan sebanyak 712 data di dalam novel ini adlah sebagai berikut.

(1) Lebih dingin dari secawan es tebak di Pasar Ateh, Bukittinggi. (hlm. 2)

Frase di Pasar Ateh dalam kalimat (1) terdiri atas di yang merupakan preposisi dasar dan diikuti oleh Pasar Ateh yang merupakan frase nomina. Frase ini memiliki perangkai di depan dan sumbu di belakang. Preposisi di merupakan perangkai dan Pasar Ateh merupakan sumbu. Frase di Pasar Ateh memiliki makna tempat posisional. 
Frase di Pasar Ateh di dalam kalimat (Lebih dingin dari secawan es tebak di Pasar Ateh, Bukittinggi.) berfungsi sebagai penanda nomina lokatif.

(2) Bagai kijang, lima orang berlompatan dengan lincah dan mengurung sosok hitam tadi. (hlm. 248)

Frase dengan lincah dalam kalimat (2) terdiri atas dengan yang merupakan preposisi dasar dan diikuti oleh lincah yang merupakan adjektiva. Frase ini memiliki perangkai di depan dan sumbu di belakang. Dengan merupakan perangkai dan lincah merupakan sumbu. Frase dengan lincah memiliki makna cara.

(3) Di tengah kabut pagi, kompleks ini seperti mengapung di udara. (hlm.29)

Frase seperti mengapung dalam kalimat (3) terdiri atas seperti yang merupakan preposisi dasar dan mengapung yang merupakan verba. Frase ini memiliki perangkai di depan dan sumbu di belakang. Seperti merupakan perangkai dan mengapung merupakan sumbu. Frase seperti mengapung memiliki makna penyamaan atau perbandingan.

(4) Sejak itu aku belajar hebat, untuk bisa juga dipilih. (hlm. 316)

Frase sejak itu dalam kalimat (4) terdiri atas sejak yang merupakan preposisi dasar dan itu yang merupakan pronomina. Frase ini memiliki perangkai di depan dan sumbu di belakang. Sejak merupakan perangkai dan itu merupakan sumbu. Frase sejak itu memiliki makna penyamaan atau perbandingan.

Pola frase eksosentris direktif Prep. Dasar + (N/A/Num) yang paling banyak muncul adalah Prep. Dasar + N yaitu sebanyak 656 frase atau sekitar 51,25\%. Prep. Dasar yang paling banyak digunakan pada jenis ini adalah preposisi di. Pola yang paling sedikit muncul adalah Prep. Dasar + Pron yaitu hanya terdapat dua bentuk atau sekitar $0,16 \%$. 
Pola frase eksosentris direktif Prep. Dasar + Prep.Denominal yang paling banyak muncul adalah ke + Preposisi Denominal dengan jumlah data sebanyak 57 frase atau $4,45 \%$, sedangkan yang paling sedikit kemunculannya adalah di + Prep. Denominal dengan jumlah data sebanyak 7 frase atau sekitar $0,55 \%$.

Pola frase eksonsentris direktif Prep. Dasar + Nomina Lokasi+ N yang paling banyak muncul adalah adalah di + depan $+\mathrm{N}$, yaitu sebanyak 38 frase atau sekitar $2,97 \%$, sedangkan yang paling sedikit adalah ke + puncak $+\mathrm{N}$, ke + depan $+\mathrm{N}$, di + ujung kanan $+\mathrm{N}$, di sepanjang $+\mathrm{N}$, di + pucuk $+\mathrm{N}$, dari + dalam $+\mathrm{N}$ sebanyak 1 data atau $0,08 \%$.

Pola frase eksosentris direktif Pola Prep. Deverbal + Prep. Dasar yaitu berbeda + dengan dan sesuai + dengan. Frase berbeda + dengan dan sesuai + dengan masingmasing terdapat sebanyak 1 frase atau sekitar $0,08 \%$.

Pola frase eksosentris direktif Prep.Denominal + (V/N/A/Pr) yang paling banyak muncul adalah Prep. Denominal + N yaitu sebanyak 139 frase atau sekitar 10,86\%. Pola yang paling sedikit muncul adalah pola Prep. Denominal + Pron yaitu sebanyak 3 frase atau sekitar $0,23 \%$.

Pola frase eksosentris direktif Prep.Deverbal + yang paling banyak muncul, yaitu sebanyak 80 frase atau sekitar $6,25 \%$. Pola yang paling sedikit muncul adalah Prep. Deverbal + Adj dan Prep. Deverbal + Num, yang masing-masing hanya terdapat 1 frase atau sekitar $0,08 \%$.

Pola frase eksosentris direktif Prep. Dekonjungsional+ yang paling banyak muncul, yaitu sebanyak 5 frase atau sekitar 0,39\%, sedangkan Prep. Dekonjungsional + $V$ adalah pola frase eksosentris direktif yang paling sedikit muncul, yaitu sebanyak 1 frase atau sekitar $0,08 \%$. 
Pola frase eksosentris direktif Deadverbial+ yang paling banyak muncul adalah Prep. Deadverbial $+V$ yaitu sebanyak 24 frase atau sekitar 1,88\%, sedangkan Prep. Deadverbial $+N$ adalah pola frase eksosentris direktif yang paling sedikit muncul, yaitu sebanyak 14 frase atau sekitar $1,09 \%$.

Dari 1280 frase eksosentris direktif terdapat 578 frase atau sekitar 45,16\% yang bermakna tempat, 70 frase eksosentris direktif atau sekitar 5,47\% yang bermakna waktu, 202 frase eksosentris direktif atau sekitar 15,78\% yang bermakna sebab. Terdapat 220 atau sekitar 17,19\% yang bermakna cara-agentif dan 210 frase eksosentris direktif atau sekitar 16,4\% yang memiliki makna lain frase eksosentris direktiif.

Kecenderungan lebih banyaknya frase eksosentris direktif yang bermakna tempat di dalam novel ini karena pengarang banyak membutuhkan kehadiran frase eksosentris direktif bermakna tempat untuk memperjelas latar ceritanya. Selain itu, kecenderungan lebih banyak ditemukan frase eksosentris direktif yang bermakna tempat berhubungan dengan banyaknya preposisi penunjuk tempat yang digunakan seperti $d i$, pada, ke, dan dari dibandingkan dengan preposisi yang lainnya. Makna frase eksosentris direktif ditentukan dari preposisi yang digunakannya.

Makna tempat frase eksosentris direktif yang paling banyak muncul adalah makna posisional yaitu sebanyak 208 frase atau sekitar 16,25\%. Makna tempat frase eksosentris direktif yang paling sedikit muncul adalah makna gerakan searah lintasan yang hanya terdapat 1 frase atau sekitar $0,08 \%$.

Makna waktu frase eksosentris direktif yang paling banyak muncul adalah makna kurun waktu, yaitu sebanyak 29 frase atau sekitar 2,27\% dan yang paling sedikit muncul adalah makna saat yang hanya terdapat 13 frase atau sekitar 1,02\%. Makna sebab-tujuan frase eksosentris direktif yang paling banyak muncul adalah makna 
penerima atau sasaran yaitu sebanyak 88 frase atau sekitar 6,88\%. Makna sebab-tujuan frase eksosentris direktif yang paling sedikit muncul adalah sebab, alasan, motif yang hanya terdapat 15 frase atau sekitar $1,17 \%$.

Makna cara-agentif frase eksosentris direktif yang paling banyak muncul adalah makna cara dan alat, agentif, objektif yaitu masing-masing sebanyak 102 frase atau sekitar 7,97\%, sedangkan makna cara-agentif frase eksosentris direktif yang paling sedikit muncul adalah makna perangsang yaitu sebanyak 7 frase atau sekitar $0,55 \%$. Makna lain frase eksosentris direktif yang paling banyak muncul adalah makna penyamaan atau perbandingan yaitu sebanyak 89 frase atau sekitar 6,95\%, sedangkan makna yang paling sedikit muncul adalah makna kekecualian yaitu sebanyak 6 frase atau sekitar $0,47 \%$.

Berdasarkan penjelasan di atas, dapat dikatakan bahwa penggunaan frase eksosentris direktif dalam novel Negeri 5 Menara cukup beragam. Hal ini terlihat dari keberagaman pola atau makna frase eksosentris direktif yang terdapat dalam novel Negeri 5 Menara. Meskipun terdapat keberagaman penggunaan frase eksosentris direktif, tidak diikuti oleh pemerataan penggunaannya. Terdapat kecenderungan yang cukup signifikan jumlah pemunculan pada pola frase eksosentris yang pertama yaitu Prep. Dasar + (N/A/Num), sedangkan terdapat dua pola yaitu Prep. Dasar + Prep. Dasar dan Prep. Dasar + Prep. Deadjektival yang tidak ditemukan penggunaannya. Dari pemunculan makna juga terdapat kecenderungan yang cukup signifikan. Makna tempat paling banyak ditemukan dalam novel Negeri 5 Menara karangan A. Fuadi ini.

Dari 1280 frase eksosentris direktif, terdapat 514 frase eksosentris direktif atau sekitar 40,16\% yang dapat digolongkan ke dalam fungsi frase eksosentris direktif jika dilihat dari persamaannya dengan afiksasi. Frase eksosentris direktif yang paling banyak 
ditemukan adalah frase eksosentris direktif yang berfungsi sebagai penanda nomina lokatif, yaitu sebanyak 435 frase atau sekitar 84,63\%. Frase eksosentris direktif yang paling banyak ditemukan selanjutnya adalah frase yang berfungsi berfungsi sebagai penanda objek tak langsung ditemukan sebanyak 53 frase atau sekitar 10,31\%, sedangkan yang paling sedikit ditemukan adalah frase yang berfungsi sebagai penanda objek langsung, yaitu sebanyak 26 frase atau sekitar 5,06\%.

Kecenderungan lebih banyaknya frase eksosentris direktif yang berfungsi sebagai penanda nomina lokatif di dalam novel ini berkaitan dengan data struktur dan makna frase eksosentris direktif yang paling banyak ditemukan karena fungsi. Karena preposisi merupakan komponen penting dalam frase eksosentris direktif, maka fungsi frase eksosentris direktif ditentukan dari fungsi preposisi di dalam kalimat. Frase eksosentris yang dirangkai dengan preposisi di dan ke yang menunjukkan makna tempat merupakan frase eksosentris direktif yang paling banyak muncul. Oleh karena itu, frase eksosentris direktif yang berfungsi sebagai penanda nomina lokatif untuk memperjelas latar tempat ceritanya.

Berdasarkan interpretasi hasil analisis yang sudah ditemukan, dapat diketahui bahwa struktur frase eksosentris direktif yang muncul dalam novel Negeri 5 Menara terdiri atas delapan jenis, yaitu Prep. Dasar + (N/A/Num), Prep. Dasar + Prep.Denominal, Prep. Dasar + Nomina Lokasi+ N. Tempat, Prep.Deverbal + Prep. Dasar, Prep.Denominal $+(\mathrm{V}, \mathrm{N}, \mathrm{A}, \mathrm{Pr})$, Prep.Deverbal $+9 \mathrm{~V} / \mathrm{Pr} / \mathrm{Aj}$, Prep. Dekonjungsional+ (N/V), dan Prep. Deadverbial+ (N/V).

Pada wacana novel tersebut, terlihat adanya penggunaan pola frase eksosentris direktif yang cukup beragam karena ditemukan kemunculan masing-masing pola frase eksosentris direktif dalam wacana novel tersebut, walaupun terdapat dua pola frase 
eksosentris direktif yang tidak ditemukan yaitu Prep. Dasar + Prep. Dasar dan Prep. Dasar + Prep. Deadjektival. Pola frase eksosentris direktif yang paling banyak muncul dalam novel Negeri 5 Menara adalah pola Prep. Dasar + (N/A/Num). Prep. Dasar $+\mathrm{N}$ dengan menggunakan preposisi di adalah pola yang paling sering muncul di antara dua jenis yang lain. Pola ini paling sering muncul karena dalam novel Negeri 5 Menara ini, pengarang banyak membutuhkan kehadiran keterangan tempat untuk melengkapi ceritanya. Pola yang paling sedikit muncul dalam novel ini adalah pola Prep. Deverbal + Prep. Dasar. Hal ini dikarenakan terbatasnya jumlah preposisi deverbal yang dapat menjadi sumbu dan dirangkai oleh preposisi dasar. Dalam novel ini ditemukan dua jenis struktur frase eksosentris direktif yang tidak termasuk dalam penggolongan struktur frase eksosentris direktif Kridalaksana, yaitu Prep. Dekonjungsional+ (N/V), dan Prep. Deadverbial+ (N/V). Kemunculan struktur baru ini menyebabkan munculnya makna baru yaitu makna perbuatan bersamaan yang dihasilkan oleh preposisi deadverbial sambil.

Makna frase eksosentris direktif adalah makna dalam novel yang timbul dari pertemuan unsur-unsur yang membentuk frase eksosentris direktif. Makna frase eksosentris direktif yang muncul dalam novel Negeri 5 Menara ini terdiri atas 5 jenis yaitu makna tempat, makna waktu, makna sebab-tujuan, makna cara-agentif, dan makna lain preposisi. Di antara kelima makna frase eksosentris direktif tersebut, makna yang paling sering muncul adalah makna tempat. Makna tempat yang paling sering muncul adalah makna tempat posisional. Hal ini sesuai dengan banyaknya pola yang paling sering muncul yaitu Prep. Dasar $(\mathrm{di})+\mathrm{N}$, karena makna frase eksosentris direktif ditentukan dari preposisi yang digunakannya. Makna yang paling sedikit penggunaannya adalah makna gerakan searah lintasan. Hal ini dikarenakan makna 
gerakan searah lintasan ini hanya untuk menjelaskan preposisi denominal. Padahal hanya ditemukan satu buah penggunaan preposisi sepanjang dalam novel ini.

Frase eksosentris direktif berkaitan dengan persamaannya denganafiksasi dalam novel ini ditemukan dalam fungsinya sebagai penanda objek langsung, penanda objek tak langsung, dan penanda nomina lokatif. Karena preposisi merupakan komponen penting dalam frase eksosentris direktif, maka fungsi frase eksosentris direktif ditentukan dari fungsi preposisi di dalam kalimat. Frase eksosentris direktif yang paling banyak muncul adalah frase eksosentris direktif yang berfungsi sebagai penanda nomina lokatif. Hal ini disebabkan karena frase eksosentris direktif yang berfungsi sebagai penanda nomina lokatif adalah frase eksosentris yang dirangkai dengan preposisi di dan ke, kedua preposisi ini termasuk dalam tiga preposisi yang paling banyak digunakan dalam novel ini. Oleh karena itu, frase eksosentris direktif yang berfungsi sebagai penanda nomina lokatif paling banyak ditemukan dalam novel ini. Selain itu, hal lain yang menyebabkan banyak ditemukannya frase eksosentris direktif yang yang berfungsi sebagai penandanomina lokatif karena pengarang banyak membutuhkan kehadiran penanda nomina lokatif untuk memperjelas latar tempat ceritanya. Dalam novel ini keterangan yang paling banyak dibutuhkan adalah mengenai keterangan tempat cerita.

Hasil penelitian ini dapat diimplikasikan dalam pembelajaran kompetensi dasar (KD) Bahasa Indonesia untuk siswa kelas XII SMA yaitu KD 3.9 menganalisis isi dan kebahasaan novel dan KD 4.9 merancang novel atau novelet dengan memperhatikan isi dan kebahasaan baik secara lisan maupun tulis.

Penelitian ini memiliki keterbatasan yaitu hanya sebatas aspek-aspek yang terdapat dalam instrumen penelitian yaitu berdasarkan pola, makna, dan fungsi frase eksosentris direktif. Sebaiknya penelitian ini juga mengkaji hal-hal lain yang berkaitan 
dengan frase eksosentris direktif. Dalam penelitian ini, fungsi frase eksosentris direktif di dalam kalimat hanya dilihat dari keterkaitannya dengan persamaan afiksasi dan preposisi. Sebaiknya penelitian ini juga mengkaji seluruh fungsi frase eksosentris direktif di dalam kalimat.

\section{KESIMPULAN}

Hasil penelitian ini menunjukkan terdapat 1280 frase eksosentris direktif yang dikaji berdasarkan pola struktur dan maknanya dalam novel Negeri 5 Menara. Makna tempat yang paling sering muncul adalah makna tempat posisional. Hal ini sesuai dengan banyaknya pola yang paling sering muncul yaitu Prep. Dasar (di) $+\mathrm{N}$. Hal ini disebabkan makna frase eksosentris direktif ditentukan dari preposisi yang digunakannya. Hasil penelitian ini dapat diimplikasikan dalam pembelajaran kompetensi dasar yang mengarahkan siswa SMA untuk memiliki kompetensi menganalisis kebahasaan novel.

\section{UCAPAN TERIMA KASIH}

Terima kasih kepada teman sejawat yang berkenan setia menjadi teman diskusi sehingga proses penelitian ini dapat berjalan lancar.

\section{DAFTAR PUSTAKA}

Chaer, A. (2009). Sintaksis bahasa Indonesia. Jakarta: Rineka Cipta.

Fuadi, A. (2009). Negeri 5 menara. Jakarta: PT Gramedia.

Kridalaksana, H. (1985). Tata bahasa deskriptif bahasa Indonesia: Sintaksis. Jakarta: Pusat Pembinaan dan Pengembangan Bahasa Depdikbud.

Ramlan, M. (2001). Sintaksis. Yogyakarta: Karyono. 